REVIEW

\title{
The contribution of cell wall remodeling and signaling to lateral organs formation
}

\author{
Zvi Duman ${ }^{\mathrm{a}, \mathrm{b}}$, Avi Eliyahu ${ }^{\mathrm{a}, \mathrm{c}}$, Mohamad Abu-Abied ${ }^{\mathrm{a}}$ and Einat Sadot ${ }^{\mathrm{a}}$

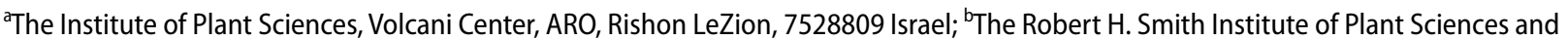 \\ Genetics in Agriculture, The Robert H. Smith Faculty of Agriculture, Food and Environment, The Hebrew University of Jerusalem, Rehovot \\ 7610001, Israel; 'The Mina \& Everard Goodman Faculty of Life Sciences, Bar-Ilan University, Ramat Gan 5290002 Israel
}

\begin{abstract}
Lateral organs are formed in plants by post embryonic developmental programs. Leaves, and flowers differentiate from the shoot apical meristem and lateral roots from the primary root pericycle meristem. Adventitious roots are roots formed from non-root lateral meristematic tissues, mostly the cambium, in many cases in response to stress signals. The ability of plants to regenerate adventitious roots is fundamental for selection and breading programs which are based on vegetative propagation of elite clones. Thus, recalcitrant plants, losing their rooting capability, may form a genuine commercial barrier in agricultural and forestry improvement programs. Some cellular mechanisms underlying adventitious root formation have been revealed, but much is yet to be clarified. The plant primary cell wall is a dynamic organ that can change its form, and perceive and relay molecular signals inward and outward during certain stages of development in particular cells. Therefore, before the secondary cell wall is deposited and plants become the wood from which walls and furniture are built, and the fibers from which cloths are woven, primary cell walls actively participate in plant cell differentiation and developmental programs. While auxin is a major regulator, cell walls are important in regulating coherent formative cell division and synchronized polar elongation of cell lineages that are necessary for lateral organ induction and formation, and collaborative cell functioning. Nevertheless, little is known of how cell wall changes are molecularly sensed and translated to intracellular signals during differentiation of adventitious roots. Here we summarize recent data linking, directly or indirectly, cell wall events to auxin signaling and to lateral or adventitious root induction and formation.
\end{abstract}

ARTICLE HISTORY

Received 5 June 2019 Accepted 12 November 2019

\section{KEYWORDS}

Adventitious root; lateral root; cell wall; cellulose; hemicellulose; pectin; auxin

\section{Introduction}

Recent comprehensive published reviews summarize various aspects concerning adventitious root formation. These include hormones interactions (Druege et al. 2016; Lakehal and Bellini 2019), decline during maturation (Pizarro and Diaz-Sala 2019), development in response to stress (Steffens and Rasmussen 2016), OMICs studies to address recalcitrance (Vilasboa et al. 2018) and more. Here we review an additional aspect; the contribution of cell wall remodeling to lateral and adventitious root formation.

\section{The cell wall}

\section{Cell wall loosening}

Primary walls of young plant cells are composed mainly of cellulose microfibrils embedded in a matrix of pectin, hemicellulose, and glycoproteins (Burton et al. 2010; Somerville et al. 2004). These components can be manipulated for cell wall loosening to enable cell expansion.

Cellulose consists of chains of $\beta-1,4$-linked glucose units. It is synthesized outside the plasma membrane by the cellulose synthase complex (CSC), which moves 
in the plasma membrane as it links glucose subunits to each other to make the cellulose microfibrils. The trajectories of CSC movement in the plasma membrane are predominantly directed by cortical microtubules (MTs) (Paredez et al. 2006).

Since microfibrils are a major load-bearing element of cell walls, and their directionality dictates the orientation of cell expansion (McFarlane et al. 2014), MTs indirectly affect cell expansion via their links to the CSC (Bringmann et al. 2012; Li et al. 2012; Oda 2015; Wasteneys and Galway 2003). For example, MT disruption by the drug oryzalin (Baskin et al. 2004) or due to a temperature-sensitive mutation in the MT-associated protein (MAP) MOR1 (Whittington et al. 2001), or other mutations in, for example, $\gamma$-tubulin (Pastuglia et al. 2006), the MT-severing protein katanin p60 (Bichet et al. 2001) and more, all result in loss of cell anisotropy and swelling (Fig. 1A).
Cellulose microfibrils appear in paracrystalline structures formed due to hydrogen bonding as well as van der Waals forces (Somerville 2006). Their hydrophobic surfaces are bound to hemicellulose, whereas their hydrophilic surfaces are bound to pectins (Cosgrove 2016).

Hemicelluloses are composed of various chains, including xyloglucans with a $\beta-1,4$-glucan backbone, (gluco)mannans with $\beta$-1,4-linked glucose and mannose residues, glucuronoarabinoxylans with a $\beta-1,4-$ linked xylan backbone, and mixed-linkage glucans bound in $\beta-1,3$ and $\beta-1,4$ linkages (Lerouxel et al. 2006). Interestingly, only minor growth defects were found in an Arabidopsis mutant lacking xyloglucans (Park and Cosgrove 2012), suggesting that the $x y$ loglucan network does not form a major load-bearing component but likely plays a role in microfibril spacing (Voxeur and Hofte 2016; Xiao et al. 2016).

A

B

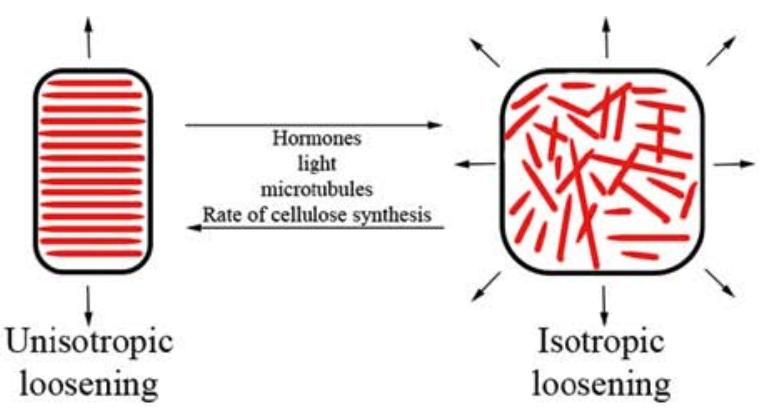

Unloosening

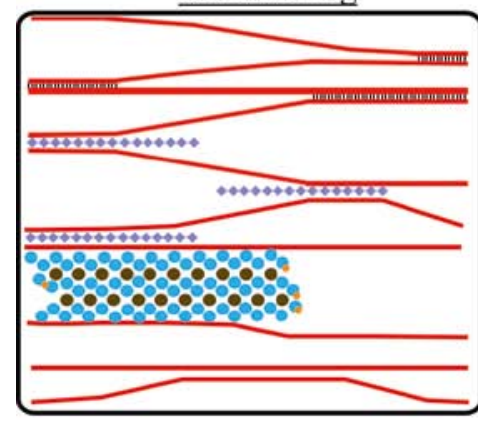

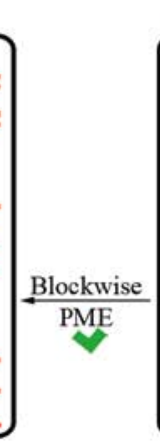

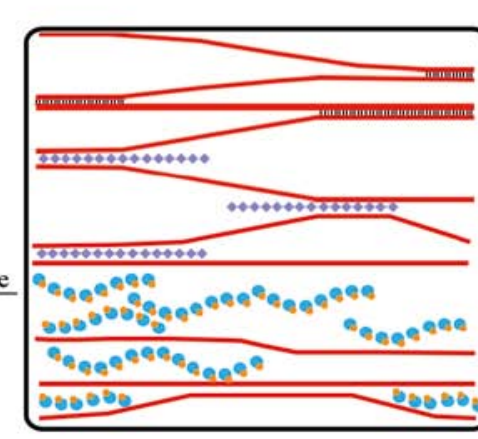

$$
\begin{aligned}
& \text { - Cellulose microfibril } \\
& \text { - Expansin } \\
& \text { Hemicellulose } \\
& \text { - Methylated pectin } \\
& \text { Calcium ion } \\
& \text {...... Hydrogen bonds }
\end{aligned}
$$

Figure 1. Mechanisms of cell wall loosening and unloosening. A. Microfibrils' orientation regulates cell expansion. While, parallel microfibrils allow polar unisotropic growth by the increment of the spaces between them, unorganized orientation of microfibrils leads to isotropic cell expansion. B. The spaces between microfibrils are dictated by hydrogen bonds between them and by the presence of hemicellulose and pectin. Cell wall loosening can be modulated by expansins which can interfere with cellulose-cellulose or cellulosehemicellulose bonding. In addition, wall loosening can result from PME activity which remove methyl residues from pectin and expose it to cleavage by pectolyases (right panel). In contrast, in a different cell context, pectin demethylation can lead to calcium bonding between the chains and wall unloosening (left panel). 
Expansins-non-enzymatic proteins with cell wallloosening activity-are suggested to target the hydrogen bonds between microfibrils separated by a monolayer of xyloglucan (Cosgrove 2016). Thus, upon cell wall acidification, expansins loosen the cell wall by facilitating the separation of tethered microfibrils (Fig. 1B).

Pectin, a homogalacturonan, consists of $a-1,4-$ linked galacturonic acids. Homogalacturonans are secreted in a highly methylesterified form and are selectively de-methylesterified by pectin methylesterases (PMEs) (Pelloux et al. 2007). PMEs can facilitate cell wall loosening when de-esterified pectin is subsequently cut by pectolytic enzymes (Pelloux et al. 2007; Xiao et al. 2014), and cell wall stiffening when de-methylesterified pectin is crosslinked with calcium ions (Chebli et al. 2012; Peaucelle et al. 2012; Rounds et al. 2011) (Fig. 1B). PMEs form a large gene family (66 in Arabidopsis, 41 in rice, 88 in poplar (Senechal et al. 2014b)) and can be regulated at the transcriptional level (Senechal et al. 2014b), by maturation following proteolytic cleavage (Senechal et al. 2014a) and by PME inhibitors (PMEls) (Wormit and Usadel 2018). Pectin can also be regulated by pectin acetylesterases, and the pectolytic enzymes polygalacturonase and pectate lyase-like, all belonging to large gene families (Senechal et al. 2014b). Pectin acetylesterases reduce pectin acetylation, thereby impairing the formation of $\mathrm{Ca}^{2+}$ bonds between homogalacturonan chains, PME activity, and pectin degradation by polygalacturonases and pectate lyase-like (Senechal et al. 2014b). Taken together, pectin integrity is regulated by a complex machinery.

\section{Cell wall signaling}

How are changes in cell wall rigidity regulated by the cell, and how do these changes convey signals back to the cell? The Catharanthus roseus plant receptor-like kinase (CrRLK1L) family, first identified from C. roseus cell cultures (Schulze-Muth et al. 1996), has emerged as containing potential receptors that can sense changes in the cell wall and then convey signals to the inside of the cell (Monshausen and Haswell 2013). The CrRLK1L family member FERONIA (FER) was first found to play a role in the communication between male and female gametophytes (Boisson-Dernier et al. 2011). In fer mutant plants, the pollen tube is attracted and penetrates the female gametophyte, but continues to grow and fails to burst and release the sperm cells (Huck et al. 2003), suggesting a defect in the perception of mechanosignals (Sanati Nezhad et al. 2013). The involvement of FER in mechano-signal transduction was confirmed in roots (Shih et al. 2014): when roots were bent, cells on the convex side exhibited a specific stretch-induced calcium signature, which changed if bending was repeated, reinforcing the dependence on mechanical status of cell walls which might change in response to mechanical stimuli (Sahaf and Sharon 2016). This typical calcium signature differed in root cells of the fer mutant, indicating that FER is a regulator of mechanical $\mathrm{Ca}^{2+}$ signaling (Shih et al. 2014). Interestingly, FER kinase activity was not essential for the mechanical calcium signal transduction (Shih et al. 2014), although its activity was proven in a self-phosphorylation assay (Escobar-Restrepo et al. 2007).

Several ligands have been found to interact with the extracellular domain of FER. Rapid ALkalinization Factor (RALF), a 5-kD secreted peptide, was found to bind to FER and initiate a downstream phosphorylation signaling cascade involving increased phosphorylation of FER itself as well as of the plasma membrane $\mathrm{H}^{+}$-ATPase AHA2 on $\mathrm{Ser}^{899}$. This was followed by inhibition of $\mathrm{H}^{+}$-ATPase activity, increased cell wall $\mathrm{pH}$, and reduced cell expansion (Haruta et al. 2014) (Fig. 2). The extracellular domain of FER and other CrRLK1L family members contains a malectin-like conserved domain (Boisson-Dernier et al. 2011), predicted to have carbohydrate-binding ability (Schallus et al. 2008). Indeed, the extracellular domain of FER has been recently shown to bind to polygalacturonic acidthe basic building block of pectin, in vitro using a gelretardation assay (Feng et al. 2018). These authors showed that the cell walls of roots soften following salt stress, and that FER is required to sense this and regulate the wall's integrity for cell recovery; in the absence of FER, cells tended to burst when growth resumed after salt stress. The proposed mechanism was that while sodium ions directly disrupt load-bearing $\mathrm{Ca}^{2+}$-pectin crosslinks in the wall, leading to cell wall loosening, FER balances this by inducing a transient, cell-specific increase in cytosolic $\mathrm{Ca}^{2+}$ to maintain wall integrity and facilitate growth recovery (Feng et al. 2018). It is not yet clear whether binding to pectin is required for the activation of FER's kinase activity and induction of $\mathrm{Ca}^{2+}$ transients. A third FER ligand is the leucine-rich repeat extensins; upon binding to FER, cell wall loosening is repressed and vacuolar expansion is inhibited (Dunser 


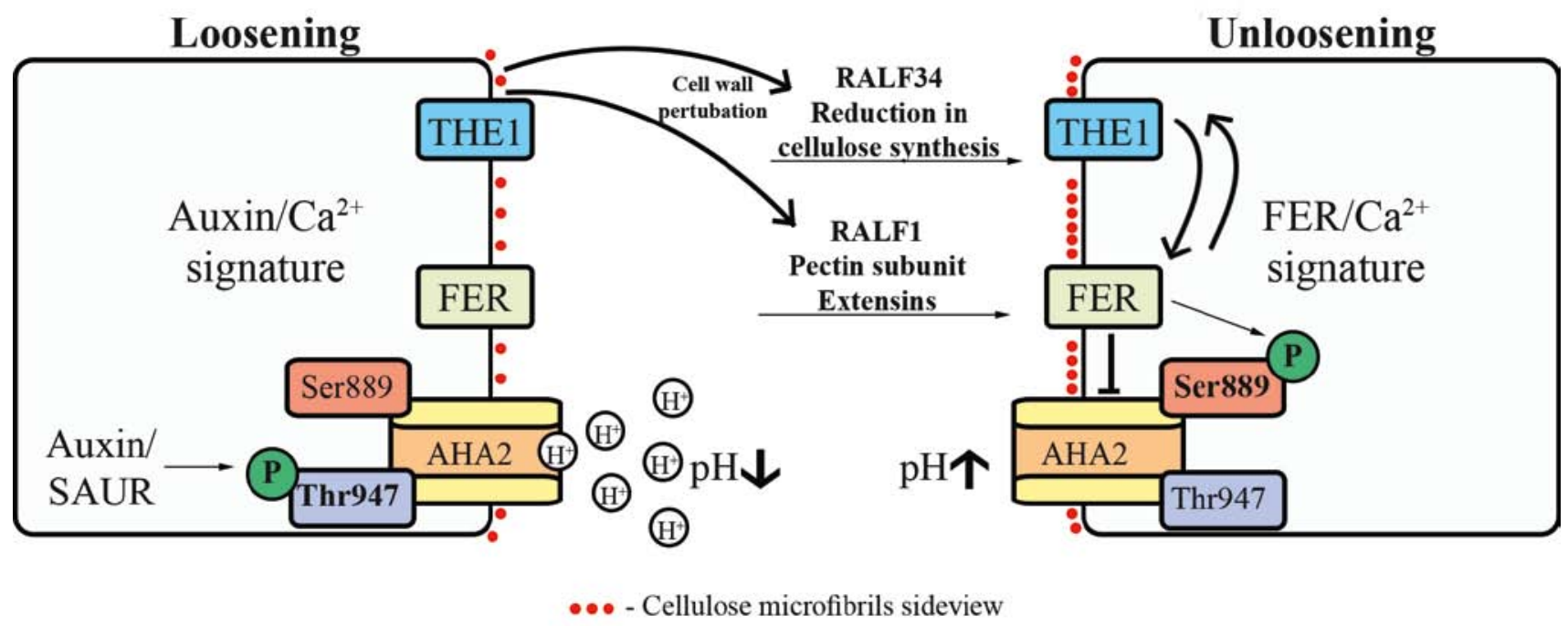

Figure 2. A simplified scheme showing the counteracting activities of auxin and FER in the modulation of cell walls. FER promote the phosphorylation of the plasma membrane H+-ATPase AHA2 on Ser899 which inhibits its activity. This leads to alkalization of the cell wall and its unloosening. The ligands that activate FER and THE1 are either peptides from the Rapid ALkalinezation Factor (RALF) family, or components of the cell wall itself. Auxin can promote cell wall loosening via SAUR proteins, which regulate the phosphorylation of the plasma membrane H+-ATPase AHA2 on Threonine 947. This leads to its activation, in turn, cell wall acidification and activation of expansins. Cell wall loosening is sensed and balanced by Catharanthus roseus plant receptor-like kinase (CrRLK1L) family members like Feronia (FER) and THESEUS1 (THE1).

et al. 2019). Leucine-rich repeat extensins are extracellular proteins. While their leucine-rich repeat domain is thought to be involved in protein-protein interactions, the extensin domain binds cell wall components (Ringli 2010). Taken together, the consequence of FER binding to each of these ligands is repression of cell wall loosening (Fig. 2). In relation to this and to the current review, it is particularly interesting to note that the fer-4 mutant has increased lateral root density (Dong et al. 2019). Similarly, while loss of expression of RALF1 increased lateral root density, overexpression of RALF1 decreased it in corresponding plants (Bergonci et al. 2014).

Another CrRLK1L is THESEUS1 (THE1) which was found to couple reduction in cellulose synthesis to the inhibition of cell elongation and to increased compensatory lignin deposition (Hematy et al. 2007). Further, it was found that RALF34, involved in lateral root induction (Murphy et al. 2016), is a ligand of THE1 (Gonneau et al. 2018). Gonneau and colleagues found that while a ralf34 mutant showed increased density of stage I lateral root primordia (Malamy and Benfey 1997) as well as aberrant formative asymmetric pericycle cell divisions, loss-of-function alleles the 1-1 and the 1-6 exhibited an increased number of stage I lateral root primordia, and atypical stage I lateral root primordia displaying extra anticlinal pericycle cell divisions
(Gonneau et al. 2018). Interestingly, RALF34 binding to THE1 was dependent on alkaline $\mathrm{pH}$. Together with the ability of RALF34 to promote alkalinization of the apoplast (Haruta et al. 2014), this suggested a possible amplification loop (Gonneau et al. 2018). Four indications were provided for the convergence of FER and THE1 signaling pathways: (i) the mutant fer-4 was resistant to growth inhibition by RALF34 (a ligand of THE1); (ii) similar genes were induced when wild-type plants were treated with RALF1 (a ligand of FER) or RALF34; (iii) expression of these genes was induced in the mutant the 1-1 by RALF1; (iv) expression of these genes was constitutive in fer-4 but not in the 1-1, suggesting that FER, in contrast to THE1, represses the expression of these genes directly (Gonneau et al. 2018), reflecting the complexity of the system (Fig. 2).

\section{The auxin-cell wall nexus}

By promoting proton pump activity, auxin induces cell wall acidification (Rayle and Cleland 1992). The molecular mechanism underlying this process has been recently revealed. It was shown that the auxin transcription-dependent pathway, including TIR/AFB$A U X / I A A$, induces the transcription of genes encoding Small Auxin Up-RNA (SAUR), which in turn are involved in activating plasma membrane $\mathrm{H}^{+}$-ATPases (Fendrych et al. 2016). SAUR are short-lived proteins, which were 
found to stimulate cell expansion. SAUR19 was shown to promote the typical phosphorylation of the plasma membrane $\mathrm{H}^{+}$-ATPase AHA2 on $\mathrm{Thr}^{947}$, which enabled the binding of 14-3-3 protein (Fuglsang et al. 1999), and its activation for wall acidification (Fig. 2). It was further demonstrated that SAUR19, as well as other SAUR proteins, binds to and represses phosphatase PP2C-D which negatively regulates $\mathrm{H}^{+}$- ATPases (Spartz 2014). As a result of cell wall acidification, the cell wall protein expansin is activated and dissociates polysaccharide complexes such as cellulose-cellulose or cellulose-hemicellulose, that form load-bearing spots, consequently leading to cell wall relaxation (Cosgrove 2005) (Fig. 1B).

Interestingly, in the root, endogenous levels of auxin in epidermal cells above and adjacent to the meristem lead to cell wall acidification and cell elongation via the SAUR19 pathway, but high levels of auxin, for example on the lower side of the root during stimulation of gravitropism, promote alkalization of cell walls and suppression of cell elongation via the FER pathway (Barbez et al. 2017). The latter was concluded following the observation that a fer- 4 mutant displays significant resistance to auxin-mediated alkalization of the cell wall.

ERULUS (ERU) is another CrRLK1L family member, regulated by auxin at the levels of transcription and phosphorylation (Schoenaers et al. 2018). It accumulates in root trichoblasts and the tips of root hairs. At the root hair plasma membrane, ERU is involved in suppressing the activity of $\mathrm{PME}$, and therefore in plants with a mutation in ERU, more de-methylesterified pectin is present leading to a different pattern of $\mathrm{Ca}^{2+}$ oscillations, slower rate of root hair growth and eventually, shorter root hairs (Schoenaers et al. 2018). Taken together, auxin restrains PME via ERU in root hairs (Fig. 3A). In this respect it should be mentioned again, that PME activity in root hair tips is known to result in calcium bonding of pectin chains, cell wall stiffening, and a transient elongation slowdown (Rounds et al. 2011). In contrast, local application of auxin triggered de-methylesterification of pectin in the naked meristem of a pin 1 (auxin transporter) mutant as determined by specific antibody which resulted in cell wall loosening and the bulging of a lateral organ (Braybrook and Peaucelle 2013), suggesting activation of PME by auxin (Fig. 3B and see also Fig. 1B for the different context dependent effects of PME on cell walls).

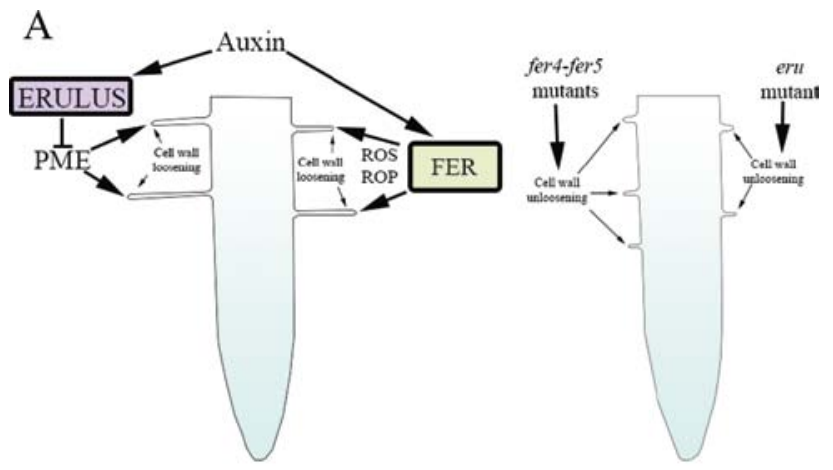

B

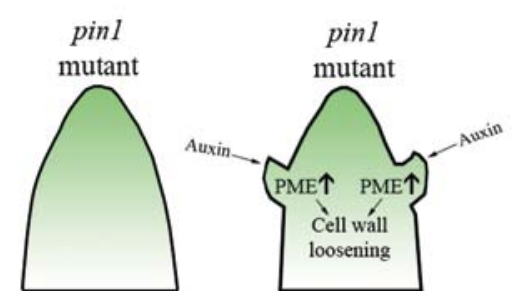

Figure 3. Different auxin/FER and auxin/PME relationships in different cells. A. Auxin promote root hair cell elongation via the function of FER in ROP/ROS dependent manner. In fer4 and fer5 auxin fail to promote root hair elongation. Auxin also regulates ERULUS in both transcription and phosphorylation dependent manner via which it restrains PME. This leads to root elongation by the modulation of pectin. B. In contrast, in the shoot apical meristem, auxin promote the activity of PME which contribute to cell wall loosening and the bulging of a lateral organ.

Phosphopeptide analysis revealed that ERU promotes the phosphorylation of FER on $\mathrm{Ser}^{701}$ located in the cytoplasmic kinase domain, and inhibits phosphorylation of AHA1/2 on $\mathrm{Ser}^{904}$ located in the autoinhibitory regulatory domain. Although it remains to be proven, this raises the possibility that auxin counteracts FER via ERU in trichoblasts (Schoenaers et al. 2018).

The auxin-FER relationship is even more complicated: auxin-mediated regulation of root hair elongation was shown to occur via FER functions in a RAC/ ROP (small GTPases) signaling pathway promoting the induction of reactive oxygen species (ROS) (Duan et al. 2010) (Fig. 3A). While auxin promoted root hair cell elongation in wild-type plants, it failed to do so in fer- 4 and fer- 5 plants. In addition, the level of activated RAC/ROPs, as well as of ROS, was reduced in fer- 4 and fer-5 seedlings relative to wild-type plants. Overexpression of GFP-ROP2 restored root hair elongation in fer-5 but not fer-4 plants, probably because of the stronger phenotype of the latter. Nevertheless, expression of pFER:::FER-GFP restored all phenotypes (Duan et al. 2010). Taken together, the auxin/FER relationships can be different in different cells. The auxin-cell 
wall ROS interplay and the molecular mechanism underlying its contribution to lateral root development were the subjects of a recent study. Confocal imaging using the ROS-specific dye DCFH-DA indicated strong ROS-mediated fluorescence in the walls of cortex cells that overlie the lateral root primordium. In addition, transmission electron microscopy was used to detect black cerium precipitates indicating the presence of $\mathrm{H}_{2} \mathrm{O}_{2}$ in the middle lamellae of cells in the flank or above the lateral root primordium during emergence (Orman-Ligeza et al. 2016). In the latter work, it was further shown that auxin promotes ROS accumulation by inducing the expression of RESPIRATORY BURST OXIDASE HOMOLOG family members (Orman-Ligeza et al. 2016).

In this respect, it is important to mention that ROS can modify cell wall properties (Foreman et al. 2003; Smirnova et al. 2014) and promote adventitious root formation in, for example, cucumber (Cucumis sativus) (Pagnussat et al. 2003; Pagnussat et al. 2004; Pagnussat et al. 2002), Eucalyptus grandis (Abu-Abied et al. 2012), marigold (Tagetes erecta L.) (Liao et al. 2012), and lateral root formation in Arabidopsis (Ma et al. 2014; Manzano et al. 2014). Taken together, auxins can modify cell walls in various ways.

Another indirect pathway through which auxin can influence cell wall properties is via its effect on MTs. Auxin activates ROP6 (Lin et al. 2012), which in turn, via its effector RIC1 and katanin, influences MT organization (Lin et al. 2013). As already noted, MTs influence cell walls by their ability to guide the CSC.

Reciprocally, modifications of the cell wall can affect auxin signaling. Reducing cellulose synthesis by genetic or pharmacological means (Feraru et al. 2011; Hamant et al. 2011; Heisler et al. 2010) or inhibiting de-methylesterification of pectin (Braybrook and Peaucelle 2013) have been shown to affect plasma membrane localization of auxin efflux carriers of the PIN proteins, suggesting the existence of feedback loops.

\section{Involvement of cell wall properties in the differentiation of lateral organs}

\section{Lateral organs from the shoot apical meristem and primary root}

Organogenesis of new primordia from the shoot apical meristem is known to depend on spatial auxin accumulation (Reinhardt et al. 2003), but the mechanical properties of the cell walls have also been shown to be critical. A new lateral organ can be triggered by local cell wall loosening induced by expansin (Pien et al. 2001), PME (Peaucelle et al. 2011), or the MT-disrupting drug oryzalin (Sassi et al. 2014). Moreover, cells at the periphery of the shoot apical meristem, where new primordia are formed, are more elastic (Kierzkowski et al. 2012). Analogous examples can be found in animal cells, in which the rigidity of the extracellular matrix influences differentiation. For example, mesenchymal stem cells undergo osteogenesis on firm collagencoated gels and myogenesis on softer collagen-coated gels (Buxboim et al. 2010; Engler et al. 2006).

Accumulated data indicate that lateral root induction and emergence are also dependent on cell wall properties. Preferential lateral root formation at the outer edge of natural root bends (Ditengou et al. 2008; Laskowski et al. 2008; Richter et al. 2009) or bends formed due to gravitropic stimuli (Peret et al. 2012) suggests the participation of mechanical signals in lateral root differentiation.

In Arabidopsis, lateral roots are formed by formative cell divisions in the pericyle, opposite the xylem pole (Laplaze et al. 2005; Malamy and Benfey 1997). This process begins when pairs of neighboring founder cells swell asymmetrically toward the common cell wall; their two nuclei migrate toward each other, followed by anticlinal division which results in the formation of two small cells flanked by two bigger ones (Fig. 4A-C). This is the stage I primordium (one cell layer). A series of additional periclinal and anticlinal divisions results in the following defined stages (Malamy and Benfey 1997).

Studies focusing on the interaction between the lateral root primordium and the cell layers above it depict complex reciprocal crosstalk. It was found that specific expression of the auxin influx carrier LAX3 in the cortex and epidermal cells directly overlying developing lateral root primordia is essential for their emergence (Swarup et al. 2008). Further, it was shown that auxin originated from the primordium itself and perceived in the upper layers leads to induction of LAX3 and cell wall-remodeling enzymes, such as pectinases, which in turn lead to separation between cells in the cortex and epidermis resulting in the opening of a route out for the newly formed lateral roots (Swarup et al. 2008). Interestingly, the endodermis - the first cell layer flanking the pericycle-responded differently, probably 
A

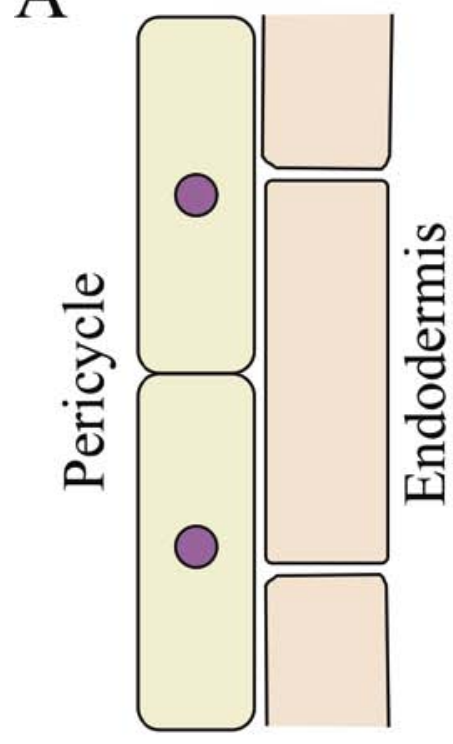

D

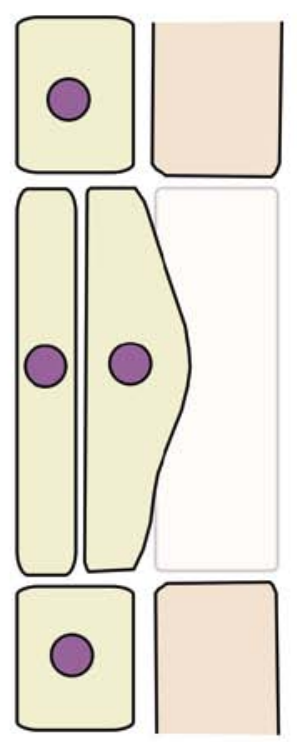

B

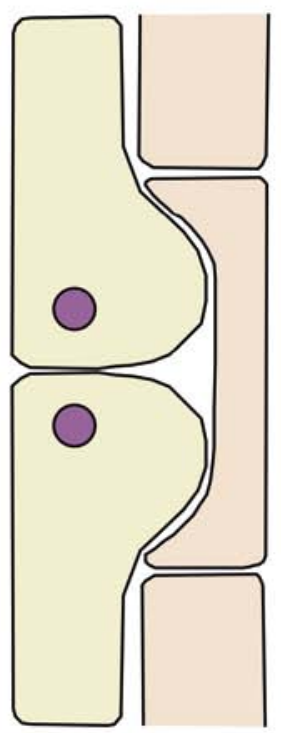

E

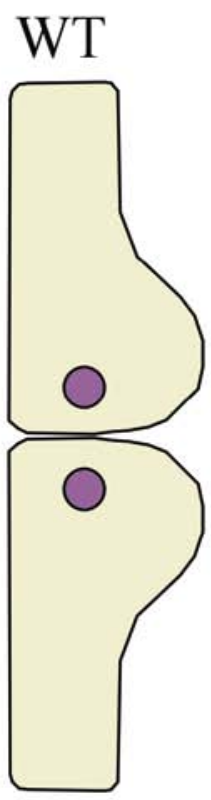

C

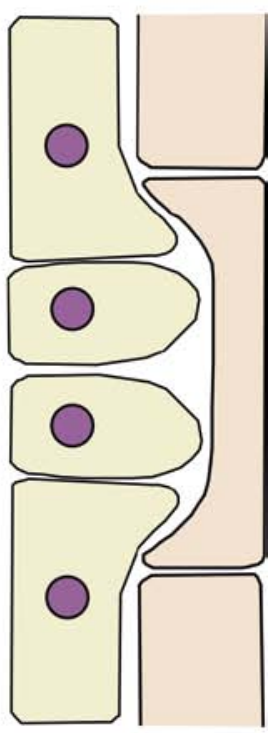

F

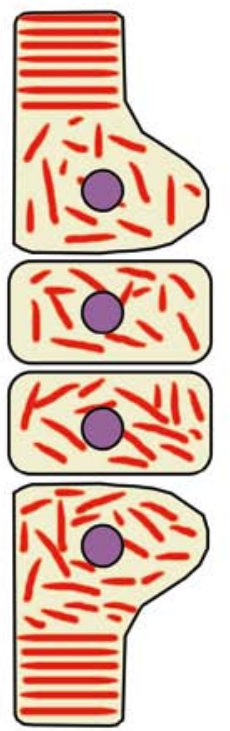

Figure 4. Mechanisms regulating asymmetric cell expansion and division in lateral root founder cells. A. The pericycle and endodermis before induction. B. Following induction the nuclei migrate to the common cell wall and asymmetric cell expansion occurs. The nearby endodermis cell accommodates the expanding cells. C. The latter is required for the asymmetric anticlinal cell division to form lateral root primordium stage I. D. Endodermal cell ablation led to pericycle cell swelling and predominantly periclinal cell divisions. This suggested that endodermal cells prevent pericycle cell swelling in the absence of specific signals. E. In expa1-1 no asymmetric pericycle cell expansion occurred, neither coordinated asymmetric cell division which suggested that particular cell wall remodeling dependent on expansin $\mathrm{A} 1$ is required. E. The asymmetric cell swelling depends on a particular microtubule organization; parallel transverse microtubules at the rare narrow side and unorganized at the common side which allow swelling.

because its casparian strips prevented full cell separation (Vermeer et al. 2014). Instead, the endodermis underwent a dramatic volume loss to accommodate lateral root growth, and penetration eventually occurred following minimal separation of the cell walls (Vermeer et al. 2014). Further investigation was performed using $S H Y 2 / I A A 3$, an auxin repressor that is widely expressed in plants, and that has been found in endodermal cells directly adjacent to lateral root primordia (Vermeer et al. 2014). It was shown that a loss-of-function mutation in SHY2/IAA3 that enhances endodermal auxin responsiveness results in accelerated lateral root emergence compared to the wild type, whereas shy2-2, an $I A A 3$ gain-of-function mutation that reduces the auxin 
responsiveness of mature endodermal cells, delayed lateral root emergence (Vermeer et al. 2014). When shy2-2 expression was restricted to endodermal cells by linking it to the CASP1 promoter, lateral root formation was blocked (Vermeer et al. 2014). Strikingly, not only primordium penetration through the endodermis was blocked, but also the very early founder cell expansion and formative divisions in the pericycle at stage I were inhibited (Vermeer et al. 2014), suggesting that the pericycle founder cells perceive mechanical signals from the endodermis. More indications for this concept were found by blocking auxin responses only in root cells overlying new lateral root primoridia in an inducible manner by expressing the stabilized auxin transcriptional repressor IAA17/AXR3 (altered auxin responses 3) under specific regulation. Upon induction, the development of lateral root primordia was delayed, and those that eventually formed exhibited abnormal shapes (Lucas et al. 2013). It was concluded that manipulation of the properties of the overlying tissues disrupted lateral root primordium morphogenesis (Lucas et al. 2013). This gained further support when abscission components playing a role in flower shedding after pollination were found to participate in cell separation for lateral root emergence. These included the peptide Inflorescence Deficient in Abscission (IDA), which signals through the leucine-rich repeat receptor-like kinases HAESA (HAE) and HAESALIKE2 (HSL2). Lower lateral root densities were found in ida single and hae/hs/2 double mutants (Kumpf et al. 2013). Closer examination showed that not only more and older lateral root primordia in the mutants were paused on the way out, unable to penetrate the different cell layers above them, but also that some of the primordia displayed an extraordinary flattened shape compared to wild-type plants (Kumpf et al. 2013). This suggested that in addition to inhibition of root emergence, lateral root primordium development itself was influenced. Furthermore, it was found that the expression of IDA depends on auxin, that loss of pectin from the middle lamella in the above layers is hampered in ida and hae/hs/2, and that the expression of cell wallmodifying enzymes such as polygalacturonases are regulated by IDA and its receptors (Kumpf et al. 2013). The above mentioned findings were elegantly summarized and illustrated in a previous review (VilchesBarro and Maizel 2015). Recently, mitogen-activated protein kinases were found to act downstream of IDA/ $\mathrm{HAE}$ to modulate pectin during lateral root emergence
(Zhu et al. 2019). The effect of endodermal cells on lateral root primordium morphogenesis at early stages was further studied by locally ablating specific cells. Ablation of endodermal cells specifically adjacent to founder cells or non-founder cells did not hamper cell division, and even induced it in cases where no previous auxin accumulation was observed. However, unlike in normal founder cell division that shows about four anticlinal divisions before the first periclinal one, following endodermal cell ablation, cell divisions were largely periclinal (Marhavy et al. 2016) (Fig. 4D). One of the first stages preceding formative cell division is cell swelling. Careful measurements showed that pericycle cell swelling can occur following the ablation of adjacent endodermal cells (Marhavy et al. 2016). Taken together, it was suggested that the endodermis participates in restraining cell division in the pericycle by mechanical prevention of their swelling. This swelling was predicted to involve (local) cell wall remodeling. By crossing different datasets related to lateral root founder cells, cell wall-remodeling proteins, auxin responsiveness, asymmetric cell division and cell-fate specification during lateral root initiation, expansin A1 was selected for further investigation (Ramakrishna et al. 2019). Indeed, expansin A1 was found to be expressed in pericycle cells, and to affect their cell wall composition. As a result, whereas swelling normally occurs on the common side of two adjacent founder cells, resulting in the typical localized bulging of these cells and in anticlinal, asymmetric cell divisions, in the expa 1-1 mutant, widening of the pericycle cells is equal and asymmetric pericycle cell division does not take place in a coordinated fashion (Fig. 4E). This, however, led only to a delay in the shift from stage I to stage II lateral root primordia but not to an overall lateral root phenotype (Ramakrishna et al. 2019).

The response to ablation of an endodermal cell and the asymmetric swelling of founder cells suggested the involvement of perception of mechanical signals and a possible role of the cytoskeleton (Landrein and Hamant 2013; Sampathkumar et al. 2014; Sassi and Traas 2015; Vilches-Barro and Maizel 2015). The role of the cytoskeleton in initial events in founder cells was carefully studied (Vilches Barro et al. 2019). When the MT marker RFP-MAP4-MBD was specifically expressed in the founder cells under the GATA23 promoter, it was found that pericycle cells at the xylem pole had longitudinal MTs, but dividing founder cells had more transverse MTs that were suitable for supporting 
anticlinal cell division. After the first division, MTs in the central domain were predominantly isotropic, an organization that allows swelling, but in the peripheral domain, they were in transverse parallel arrays (Vilches Barro et al. 2019) (Fig. 4F). To confirm that this specific organization is critical for the asymmetric swelling, MTs were specifically disrupted in founder cells by expressing the atypical tubulin kinase/phosphatase propyzamide-hypersensitive 1 (Fujita et al. 2013b) in its phosphatase inactive form (PHS1 $\triangle \mathrm{P})$ under a specific inducible promoter (Vilches Barro et al. 2019). Disruption of MTs led to symmetric swelling of the founder cells. Furthermore, disruption of auxin signaling specifically in founder cells or in adjacent endodermal cells inhibited the asymmetric swelling (Vilches Barro et al. 2019), providing evidence of important auxin-MT crosstalk. By suppressing LBD16 (Lateral organ Boundaries-Domain 16) and as a result, polar nucleus migration (Goh et al. 2012), MTs were found to be equally organized along the cells, allowing symmetric swelling. Therefore, reorganization of cortical MTs requires auxin signaling and LBD16-dependent polar migration of the founder cell's nuclei. Interestingly, the polar nuclear migration was dependent on actin (Vilches Barro et al. 2019). Taken together, fine tuning of asymmetrical cell wall modulation plays a role in lateral root induction.

Another cell wall component affecting lateral root formation is callose. It was shown that cells in the early lateral root primordium are connected to the surrounding cells by conductive plasmodesmata, but that during stages IV and V, an increased amount of callose is deposited and the primordium becomes isolated from the surrounding cells until emergence (BenitezAlfonso et al. 2013). Mutants for the callose-degrading enzymes PdBG1 and PdBG2 formed an increasing number of lateral roots that touched each other, suggesting that callose accumulation and reduction of plasmodesmatal conductivity at early stages prevent the transport of suppressive signals from the differentiating lateral root to its vicinity (Benitez-Alfonso et al. 2013).

An important finding linking cell wall modifications to lateral root formation was obtained by comparing lateral root density in a series of mutants in different components of the cell wall (Roycewicz and Malamy 2014). It was shown that mutations in (i) LRD5/XEG113, which results in reduced arabinosylation of extensins in the cell wall (Gille et al. 2013), (ii) the gene encoding
Reduced Arabinose Yariv1 (RAY1) playing a role in arabinosylation of cell wall arabinogalactan proteins (Gille et al. 2013), (iii) xylosyltransferase genes (xxt1/xxt2), resulting in plants deficient in xyloglucan (Cavalier et al. 2008), and the mutants (iv) mur1, which is deficient in fucose de-novo synthesis, (v) mur3 deficient in fucose, (vi) mur4 deficient in arabinose, (vii) mur8 deficient in rhamnose, (viii) mur10 and mur11 exhibiting complex changes in monosaccharides (Reiter et al. 1997), (ix) procuste 1 in the cellulose synthase CESA6 subunit (Fagard et al. 2000) and (x) cesa3 in the cellulose synthase CESA3 subunit (Roycewicz and Malamy 2014) all give rise to increased numbers of lateral roots. While it was shown that Ird5 led to increased lateral root emergence (Roycewicz and Malamy 2014), in the rest of the mutants, it has yet to be determined whether lateral root induction and/or emergence is affected.

\section{Adventitious roots}

\section{Cell wall modifications affecting adventitious root formation}

Adventitious roots differentiate from non-root tissues. Differences and similarities between lateral and adventitious roots have been outlined in terms of tissue of origin, genetic regulation, balance of hormones and environmental effects (Bellini et al. 2014; Verstraeten et al. 2014), but much less is known about the effect of cell wall modifications on adventitious root formation. Nevertheless, some data have been accumulated from different plant species.

In rice, it was shown that adventitious root primordia generate a mechanical force of about 18 millinewtons within $1 \mathrm{~h}$ on the epidermis which signals epidermal cell death in an $\mathrm{H}_{2} \mathrm{O}_{2}$ - and ethylene-dependent manner (Steffens et al. 2012). Adventitious roots are formed as part of the natural development program in rice and the contribution of cell wall properties to their penetration through deeper cell layers has yet to be determined. Of note, ethylene has been shown to promote cell wall modifications during fruit ripening (Forlani et al. 2019) and formation of an abscission zone (Merelo et al. 2017). In addition, xyloglucan endotransglucosylases/hydrolases and a-expansins were enhanced by ethylene in roots of mung bean (Huang et al. 2013).

In pine, the expression of expansin is dramatically and transiently increased in the base of cuttings treated with auxin (Hutchison et al. 1999). Although hard to 
prove in pine trees, it is tempting to speculate that the latter is relevant to adventitious root formation.

In poplar it was found that among the highly expressed transcripts during the early stage of adventitious root formation were those encoding for cell wall remodeling proteins like glycoside hydrolases, pectate lyases, pectin esterases and expansins (Rigal et al. 2012).

Evidence provided from Arabidopsis suggests that indeed, cell wall modifications are relevant to adventitious root formation. In the PME3 mutant atpme3-1, reduced activity of PME and changes in methylesterification of galacturonic acid were correlated with increased formation of adventitious roots (Guenin et al. 2011). The importance of fine tuning pectin methylesterification was also shown to play a role in dormant or active poplar cambium where the activity of different PME isoenzymes was determined. It was found that while the activity of a neutral PME was equally dispersed throughout the cross section of both dormant and active stems, a major peak in the activity of basic PME characterized the active cambium region but not the dormant cambium. Lower activity of PME with acidic isoelectric point was found on both sides of the active cambium and was related to differentiating phloem and xylem cells (Micheli et al. 2000). This suggests that high specific PME activity correlates with cambium activity, which is the tissue that gives rise to adventitious root differentiation (Fahn 1990). In this respect, it is interesting to mention differential immunofluorescence staining using antibodies specific to methylesterified (JIM5) or de-methylesterified (LM20) pectin (Knox et al. 1990; Verhertbruggen et al. 2009) in adventitious roots or callus formed following IBA (indole 3 butyric acid) treatment of cuttings from mature Eucalyptus brachyphylla (Eliyahu et al. 2020, this issue). Mature Eucalyptus trees are very difficult to root and often form callus instead of roots when are treated with the auxin IBA. It is now shown that callus cells differ from root cells in their cell wall composition. It was found in parenchyma-like cells that whereas methylesterified pectin (detected by JIM5 antibody) was deposited mainly in cell junctions in the root, it was found throughout the cell wall in the callus. Furthermore, cells formed in the callus exhibited more demethylesterified pectin compared to roots (detected by LM20 antibody). This provided another view of the complexity of cell wall regulation in relation to adventitious root differentiation. However, at this point, it is hard to conclude which pectin modification in which cells will contribute to adventitious root formation in each plant.

Another study addressed the question of how mutations in MT-associated proteins or cellulose synthesis affect adventitious root formation. Plants overexpressing RIC1 (RIC1-OX3) produced more adventitious roots than control wild-type plants. Of note, RIC1 is a ROP GTPase effector protein shown to promote MT bundle formation and the activation of katanin-mediated MT severing (Fu et al. 2005; Lin et al. 2013). In contrast, a mutant in katanin, bot1-1 (Bichet et al. 2001), barely made any adventitious roots under the same conditions. In addition, two temperature-sensitive alleles of the MT-associated protein MOR1, mor1-1 (Whittington et al. 2001) and rid5 (Konishi and Sugiyama 2003), made less adventitious roots than the wild type at the restrictive temperature (Abu-Abied et al. 2015b). Auxin applied to mor1-1 or rid5 at the restrictive temperature, or to wild-type plants in the presence of the MT-disrupting drug oryzalin, led to the formation of amorphous cell clusters, reminiscent of the callus formed when auxin is applied to cuttings from mature trees (Eliyahu et al. 2020, this issue). The importance of MT-related proteins to adventitious root formation was further demonstrated by showing that MOR1 promoter induces the expression of GFP in the pericycle and adventitious root primordium (Abu-Abied et al. 2015a). Taken together, it was concluded that fine tuning of MT dynamics and/or organization is critical for adventitious root induction in Arabidopsis. In this respect, it is interesting to note that induced expression of wall-remodeling genes was found in the shoot apical meristem of a double mutant for the auxin transporter PIN1 and katanin, pin 1-6/bot1-7. Unlike the naked meristem of pin 1-6, lateral organs emerged from the shoot apical meristem of the double mutant pin 16/bot 1-7, suggesting that perturbation of MTs promoted the expression of wall-remodeling genes, which affected the cell walls locally and promoted lateral organ development (Armezzani et al. 2018).

In Eucalyptus grandis, the expression of several MTrelated genes differed between easy-to-root juvenile cuttings and difficult-to-root mature cuttings during adventitious root induction by IBA. Further, the rate of adventitious root formation from mature cuttings increased significantly in the presence of a combined treatment that included IBA and low doses of the MTdisrupting drug trifluralin (Abu-Abied et al. 2014). The 
latter suggested that mild perturbation of MTs facilitates a positive change in MT dynamics and/or cell wall properties, or other unknown changes favoring adventitious root induction and formation.

The effect of cellulose synthesis on adventitious root formation was addressed. When adventitious roots were induced in any 1 plants which have a mild mutation in the CESA1 subunit (Fujita et al. 2013a), adventitious root formation was higher than in the wild type (Abu-Abied et al. 2015b). Induction of adventitious root formation with auxin in the presence of the cellulose synthesis inhibitor isoxaben culminated in the formation of amorphous cell clusters, again reminiscent of the callus formed in recalcitrant trees after IBA treatment.

Reduced cellulose synthesis due to defects in exocytosis was found in the $3 \mathrm{KO}$ (xik/xi1/xi2) triple mutant for myosin $\mathrm{Xl}$, actin-based motor proteins that propel membrane trafficking (Zhang et al. 2019). This same $3 \mathrm{KO}$ mutant had higher lateral root density and higher rate of adventitious root formation than wildtype plants (Abu-Abied et al. 2018). Although mild defects were also found in these plants in polar auxin transport and cell division (Abu-Abied et al. 2018), one cannot rule out the possibility that changes in wall properties also contribute to the increased number of post-embryonic roots.

When more cell wall mutants were tested, it was found that compared to the wild type, the xyloglucandeficient mutant $x \times 1 / x \times 2$ (Cavalier et al. 2008) formed more lateral and adventitious roots, the fucosedeficient mur3-1 (Reiter et al. 1997) formed similar numbers of both root types, the mild CESA 1 mutant any 1 (Fujita et al. 2013a) made significantly more lateral and adventitious roots (Abu-Abied et al. 2015b), and the CESA3 mutant cev1 (Ellis et al. 2002) made more lateral roots but the same amount of adventitious roots. Interestingly, the CESA6 mutant prc1 (Fagard et al. 2000) made similar amounts of lateral roots but less adventitious root than the wild type (Fig. 5).

\section{Etiolation as a method to modulate cell walls and promote adventitious root formation}

Some creative methods have been developed to successfully induce rooting in plants that do not respond to the common auxin treatments. Among these methods is etiolation of the cuttings prior to root induction by auxin (Hartmann et al. 2011). In some plants, such as avocado, rooting of vegetative rootstocks absolutely requires an etiolation step (Brokaw 1975; Frolich and Platt 1972). The relevant changes occurring in the adventitious root founder cells and surrounding tissues during etiolation that allow root differentiation in recalcitrant plants have yet to be determined.

Some of the cellular modifications that occur during etiolated Arabidopsis plant growth have been documented. For example, decreased velocity of the CSC was measured in dark grown Arabidopsis plants, leading to inhibition of cellulose deposition (Bischoff et al. 2011). In addition, atomic force microscopy showed that the stiffness of the longitudinal walls of cells that are just starting to elongate below the hook of the etiolated hypocotyl is less than the stiffness of the transverse walls, a change that precedes the organization of MTs in parallel arrays, $90^{\circ}$ to the growth axis (Peaucelle et al. 2015). Interestingly, this asymmetric stiffness was suppressed by overexpression of either PME5 or PMEI3, or light. Immunostaining with antibody specific to de-methylesterified pectin showed higher staining in the longitudinal walls, indicating that cell wall weakening was related to non-methylated pectin (Peaucelle et al. 2015). Therefore, increased elongation of cells in etiolated hypocotyls was promoted by asymmetric cell wall loosening following local pectin de-methylesterification.

Partial hydrolysis of pectin can lead to the accumulation of oligogalacturonides that are chemically unmodified fragments of homogalacturonan (Ferrari et al. 2013). Oligogalacturonides are known to be defenseresponse elicitors involved in the wound response, but they might also have a role in growth and development (Ferrari et al. 2013). It was shown that very short oligogalacturonides such as (GalA)3 and (GalA)4 are produced in etiolated seedlings and can generate a dark signal to suppress photomorphogenesis (Sinclair et al. 2017). This was demonstrated in some cell-walldefective mutants that develop in the dark as if there was light. In these plants, etiolated growth recovery occurred by adding very short oligogalacturonides, suggesting their function as a dark signal in cell-cell communication (Sinclair et al. 2017). Of note, oligogalacturonides were shown to inhibit auxin signaling (Savatin et al. 2011) and to bind to the kinase receptor WAK1 (Brutus et al. 2010), which in turn is required for cell expansion (Wagner and Kohorn 2001). Interestingly, while the oligogalacturonides produced in the dark promote cell expansion (Sinclair et al. 2017), other pectin fragments which activate FER arrest cell expansion 


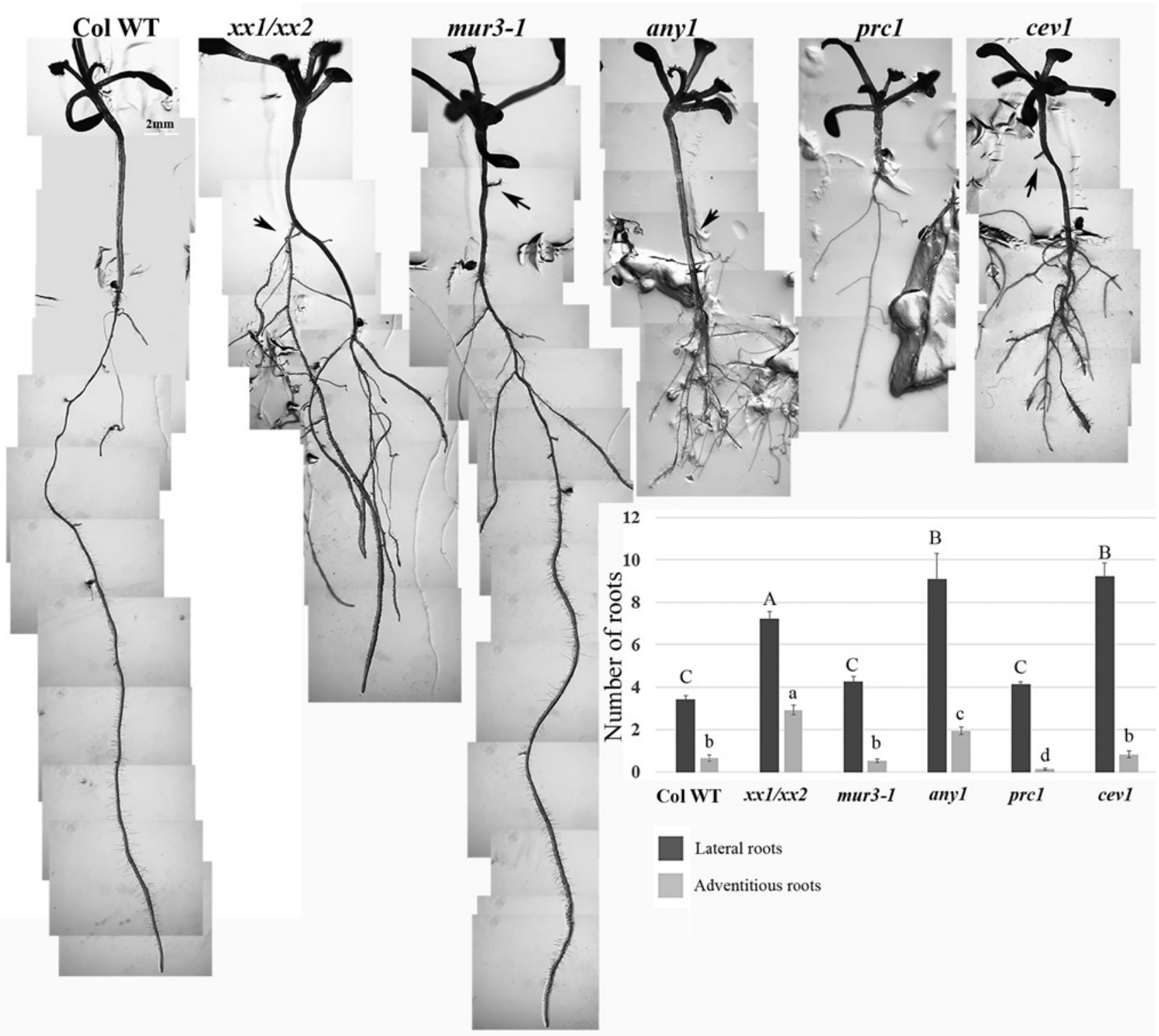

Figure 5. Adventitious and lateral root formation in mutants of cell wall-related genes. Adventitious roots were induced as previously described (Gutierrez et al. 2009). From each line, 40-70 seedlings were scored for adventitious and lateral roots. Bars with different letters represent significantly different results by Student's t-test $(p<0.05)$. Arrows show adventitious root growing from the hypocotyl. $x x 1 /$ $x x 2$ is a mutant lacking xyloglucan, a major component of hemicellulose, mur3-1 deficient in fucose, might affect both hemicellulos and pectin, any 1 has a mild mutation in CESA1 subunit of the cellulose synthase, pcr1, has a mutation in CESA6 and cev1 in CESA4 subunit.

(Feng et al. 2018). Whether these signaling pathway components are relevant to adventitious root induction in etiolated cuttings remains to be determined.

\section{Conclusions}

Spatial and temporal optimization of the cell wall properties of meristematic cells and their flanking cells, i.e., not too weak but not too rigid, is required for normal adventitious root formation. This concept is demonstrated by the increased number of adventitious roots in the mild CESA1 mutation any 1 (Fujita et al. 2013a) and in mutant $x \times 1 / x \times 2$, the cells of which are more extensible than the wild type (Park and Cosgrove 2012). In contrast, the more severe CESA6 mutation prc1 (Desnos et al. 1996) suppresses adventitious root formation (Fig. 5). Accordingly, we suggest that in mature trees, loss of adventitious root formation ability is at least partially triggered by changes in the cell wall. The contribution of etiolation to adventitious root formation in mature trees might be, among other things, in weakening the cell walls due to changes in cellulose 
Table 1. Summary of genes/mutations related to the cell wall or cytoskeleton and affecting lateral root (LR) and adventitious root (AR) formation.

\begin{tabular}{|c|c|c|c|c|}
\hline No. & Gene/mutant & Activity & Affected root & Reference \\
\hline 1 & fer-4 & Receptor-like kinase & LR & (Dong et al. 2019) \\
\hline 2 & RALF1 & Peptide ligand of FER & LR & (Bergonci et al. 2014) \\
\hline 3 & THE 1 & Receptor-like kinase & LR & (Gonneau et al. 2018) \\
\hline 4 & RALF34 & Peptide ligand of THE 1 & LR & (Murphy et al. 2016) \\
\hline 5 & RIC1-OX3 & Effector of ROP (influences microtubules) & $A R$ & (Abu-Abied et al. 2015b) \\
\hline 6 & bot1-1 & Katanin, microtubule-severing protein & $A R$ & (Abu-Abied et al. 2015b) \\
\hline 7 & rid5 & MOR1, microtubule-associated protein & AR & (Konishi and Sugiyama 2003) \\
\hline 8 & mor1-1 & MOR1, microtubule-associated protein & AR & (Abu-Abied et al. 2015b) \\
\hline 9 & ida & Peptide ligand of HAE and HSL2 & LR & (Kumpf et al. 2013) \\
\hline 10 & hae/hs/2 & Receptor-like kinases & $\mathrm{LR}$ & (Kumpf et al. 2013) \\
\hline 11 & EXPANSINA1 & Expansin & $\mathrm{LR}$ & (Ramakrishna et al. 2019) \\
\hline 12 & LRD5/XEG113 & Reduced arabinosylation of extensins & LR & (Roycewicz and Malamy 2014) \\
\hline 13 & RAY1 & Arabinosylation of arabinogalactan proteins & $\mathrm{LR}$ & (Roycewicz and Malamy 2014) \\
\hline 14 & $x x t 1 / x x t 2$ & Xylosyltransferase & $\mathrm{LR}, \mathrm{AR}$ & (Roycewicz and Malamy 2014) + Fig. 1 \\
\hline 15 & mur1 & Fucose synthesis & LR & (Roycewicz and Malamy 2014) \\
\hline 16 & mur3 & Deficient in fucose & LR & (Roycewicz and Malamy 2014) \\
\hline 17 & mur10, mur11 & Changes in monosaccharides & $\mathrm{LR}$ & (Roycewicz and Malamy 2014) \\
\hline 19 & procuste1 & CESA6 & LR, AR & (Roycewicz and Malamy 2014) + Fig. 1 \\
\hline 20 & cesa3, cev1 & CESA3 & LR & (Roycewicz and Malamy 2014) + Fig. 1 \\
\hline 21 & any 1 & CESA1 & $L R, A R$ & (Abu-Abied et al. 2015b) + Fig. 1 \\
\hline 21 & PME3 & Pectin methylesterase & AR & (Guenin et al. 2011) \\
\hline
\end{tabular}

synthesis (Bischoff et al. 2011) and/or pectin methylesterification (Peaucelle et al. 2015). The specific signaling pathways regulating cell wall properties during adventitious root induction and formation, and the affected components-cellulose, hemicellulose, pectin, expansins and others-still need to be determined in the different plants and relevant mutants, some of which are summarized in Table 1.

\section{References}

Abu-Abied, M., Belausov, E., Hagay, S., Peremyslov, V., Dolja, V., Sadot, E. (2018). Myosin XI-K is involved in root organogenesis, polar auxin transport, and cell division. J. Exp. Bot. 69: 2869-2881.

Abu-Abied, M., Mordehaev, I., Sunil Kumar, G.B., Ophir, R., Wasteneys, G.O., Sadot, E. (2015a). Analysis of MicrotubuleAssociated-Proteins during IBA-Mediated Adventitious Root Induction Reveals KATANIN Dependent and Independent Alterations of Expression Patterns. PLoS One. 10: e0143828.

Abu-Abied, M., Rogovoy Stelmakh, O., Mordehaev, I., Grumberg, M., Elbaum, R., Wasteneys, G.O., Sadot, E. (2015b). Dissecting the contribution of microtubule behaviour in adventitious root induction. J. Exp. Bot. 66(9): 2813-2824.

Abu-Abied, M., Szwerdszarf, D., Mordehaev, I., Levy, A., Stelmakh, O.R., Belausov, E., Yaniv, Y., Uliel, S., Katzenellenbogen, M., Riov, J., Ophir, R., Sadot, E. (2012). Microarray analysis revealed upregulation of nitrate reductase in juvenile cuttings of Eucalyptus grandis, which correlated with increased nitric oxide production and adventitious root formation. Plant $J$. 71: 787-799.

Abu-Abied, M., Szwerdszarf, D., Mordehaev, I., Yaniv, Y., Levinkron, S., Rubinstein, M., Riov, J., Ophir, R., Sadot, E. (2014). Gene expression profiling in juvenile and mature cuttings of
Eucalyptus grandis reveals the importance of microtubule remodeling during adventitious root formation. BMC Genomics. 15: 826.

Armezzani, A., Abad, U., Ali, O., Andres Robin, A., Vachez, L., Larrieu, A., Mellerowicz, E.J., Taconnat, L., Battu, V., Stanislas, T., Liu, M., Vernoux, T., Traas, J., Sassi, M. (2018). Transcriptional induction of cell wall remodelling genes is coupled to microtubule-driven growth isotropy at the shoot apex in Arabidopsis. Development. 145.

Barbez, E., Dunser, K., Gaidora, A., Lendl, T., Busch, W. (2017). Auxin steers root cell expansion via apoplastic $\mathrm{pH}$ regulation in Arabidopsis thaliana. Proc. Natl. Acad. Sci. U S A. 114: E4884-e4893.

Baskin, T.I., Beemster, G.T., Judy-March, J.E., Marga, F. (2004). Disorganization of cortical microtubules stimulates tangential expansion and reduces the uniformity of cellulose microfibril alignment among cells in the root of Arabidopsis. Plant Physiol. 135: 2279-2290.

Bellini, C., Pacurar, D.I., Perrone, I. (2014). Adventitious roots and lateral roots: similarities and differences. Annu. Rev. Plant Biol. 65: 639-666.

Benitez-Alfonso, Y., Faulkner, C., Pendle, A., Miyashima, S., Helariutta, Y., Maule, A. (2013). Symplastic intercellular connectivity regulates lateral root patterning. Dev. Cell. 26: 136147.

Bergonci, T., Ribeiro, B., Ceciliato, P.H., Guerrero-Abad, J.C., SilvaFilho, M.C., Moura, D.S. (2014). Arabidopsis thaliana RALF1 opposes brassinosteroid effects on root cell elongation and lateral root formation. J. Exp. Bot. 65: 2219-2230.

Bichet, A., Desnos, T., Turner, S., Grandjean, O., Hofte, H. (2001). BOTERO1 is required for normal orientation of cortical microtubules and anisotropic cell expansion in Arabidopsis. Plant J. 25: 137-148.

Bischoff, V., Desprez, T., Mouille, G., Vernhettes, S., Gonneau, M., Hofte, H. (2011). Phytochrome regulation of cellulose synthesis in Arabidopsis. Curr. Biol. 21: 1822-1827. 
Boisson-Dernier, A., Kessler, S.A., Grossniklaus, U. (2011). The walls have ears: the role of plant CrRLK1Ls in sensing and transducing extracellular signals. J. Exp. Bot. 62: 15811591.

Braybrook, S.A., Peaucelle, A. (2013). Mechano-chemical aspects of organ formation in Arabidopsis thaliana: the relationship between auxin and pectin. PLoS One. 8: e57813.

Bringmann, M., Li, E., Sampathkumar, A., Kocabek, T., Hauser, M.T., Persson, S. (2012). POM-POM2/cellulose synthase interacting 1 is essential for the functional association of cellulose synthase and microtubules in Arabidopsis. Plant Cell. 24: 163-177.

Brokaw, W.H. (1975). Rootrot resistant avocado clonal rootstocks. Plant Prop. 21: 7-8.

Brutus, A., Sicilia, F., Macone, A., Cervone, F., De Lorenzo, G. (2010). A domain swap approach reveals a role of the plant wall-associated kinase 1 (WAK1) as a receptor of oligogalacturonides. Proc. Natl. Acad. Sci. U S A. 107: 9452-9457.

Burton, R.A., Gidley, M.J., Fincher, G.B. (2010). Heterogeneity in the chemistry, structure and function of plant cell walls. Nat. Chem. Biol. 6: 724-732.

Buxboim, A., Ivanovska, I.L., Discher, D.E. (2010) Matrix elasticity, cytoskeletal forces and physics of the nucleus: how deeply do cells 'feel' outside and in? J. Cell Sci. 123: 297-308.

Cavalier, D.M., Lerouxel, O., Neumetzler, L., Yamauchi, K., Reinecke, A., Freshour, G., Zabotina, O.A., Hahn, M.G., Burgert, I., Pauly, M., Raikhel, N.V., Keegstra, K. (2008). Disrupting two Arabidopsis thaliana xylosyltransferase genes results in plants deficient in xyloglucan, a major primary cell wall component. Plant Cell. 20: 1519-1537.

Chebli, Y., Kaneda, M., Zerzour, R., Geitmann, A. (2012). The cell wall of the Arabidopsis pollen tube--spatial distribution, recycling, and network formation of polysaccharides. Plant Physiol. 160: 1940-1955.

Cosgrove, D.J. (2005). Growth of the plant cell wall. Nat. Rev. Mol. Cell. Biol. 6: 850-861.

Cosgrove, D.J. (2016). Catalysts of plant cell wall loosening. F1000Res. 5.

Desnos, T., Orbovic, V., Bellini, C., Kronenberger, J., Caboche, M., Traas, J., Hofte, H. (1996). Procuste1 mutants identify two distinct genetic pathways controlling hypocotyl cell elongation, respectively in dark- and light-grown Arabidopsis seedlings. Development. 122: 683-693.

Ditengou, F.A., Teale, W.D., Kochersperger, P., Flittner, K.A., Kneuper, I., van der Graaff, E., Nziengui, H., Pinosa, F., Li, X., Nitschke, R., Laux, T., Palme, K. (2008). Mechanical induction of lateral root initiation in Arabidopsis thaliana. Proc. Natl. Acad. Sci. US A. 105: 18818-18823.

Dong, Q., Zhang, Z., Liu, Y., Tao, L.Z., Liu, H. (2019). FERONIA regulates auxin-mediated lateral root development and primary root gravitropism. FEBS Lett. 593: 97-106.

Druege, U., Franken, P., Hajirezaei, M.R. (2016). Plant hormone homeostasis, signaling, and function during adventitious root formation in cuttings. Front. Plant Sci. 7: 381.

Duan, Q., Kita, D., Li, C., Cheung, A.Y., Wu, H.M. (2010). FERONIA receptor-like kinase regulates RHO GTPase signaling of root hair development. Proc. Natl. Acad. Sci. U S A. 107: 17821-17826.
Dunser, K., Gupta, S., Herger, A., Feraru, M.I., Ringli, C., KleineVehn, J. (2019). Extracellular matrix sensing by FERONIA and Leucine-Rich Repeat Extensins controls vacuolar expansion during cellular elongation in Arabidopsis thaliana. EMBO J.

Ellis, C., Karafyllidis, I., Wasternack, C., Turner, J.G. (2002). The Arabidopsis mutant cev1 links cell wall signaling to jasmonate and ethylene responses. Plant Cell. 14: 1557-1566.

Engler, A.J., Sen, S., Sweeney, H.L., Discher, D.E. (2006). Matrix elasticity directs stem cell lineage specification. Cell. 126: 677-689.

Escobar-Restrepo, J.-M., Huck, N., Kessler, S., Gagliardini, V., Gheyselinck, J., Yang, W.-C., Grossniklaus, U. (2007). The FERONIA Receptor-like Kinase Mediates Male-Female Interactions During Pollen Tube Reception. Science. 317: 656-660.

Fagard, M., Desnos, T., Desprez, T., Goubet, F., Refregier, G., Mouille, G., McCann, M., Rayon, C., Vernhettes, S., Hofte, H. (2000). PROCUSTE1 encodes a cellulose synthase required for normal cell elongation specifically in roots and darkgrown hypocotyls of Arabidopsis. Plant Cell. 12: 2409-2424.

Fahn, A. (1990). Plant Anatomy. Fourth Edition, Pergamon Press.

Fendrych, M., Leung, J., Friml, J. (2016). TIR1/AFB-Aux/IAA auxin perception mediates rapid cell wall acidification and growth of Arabidopsis hypocotyls. Elife. 5.

Feng, W., Kita, D., Peaucelle, A., Cartwright, H.N., Doan, V., Duan, Q., Liu, M.C., Maman, J., Steinhorst, L., Schmitz-Thom, I., Yvon, R., Kudla, J., Wu, H.M., Cheung, A.Y., Dinneny, J.R. (2018). The FERONIA Receptor Kinase Maintains Cell-Wall Integrity during Salt Stress through $\mathrm{Ca}(2+)$ Signaling. Curr. Biol. 28: 666$675 . e 665$.

Feraru, E., Feraru, M.I., Kleine-Vehn, J., Martiniere, A., Mouille, G., Vanneste, S., Vernhettes, S., Runions, J., Friml, J. (2011). PIN polarity maintenance by the cell wall in Arabidopsis. Curr. Biol. 21: 338-343.

Ferrari, S., Savatin, D.V., Sicilia, F., Gramegna, G., Cervone, F., Lorenzo, G.D. (2013). Oligogalacturonides: plant damageassociated molecular patterns and regulators of growth and development. Front. Plant Sci. 4: 49.

Foreman, J., Demidchik, V., Bothwell, J.H., Mylona, P., Miedema, H., Torres, M.A., Linstead, P., Costa, S., Brownlee, C., Jones, J.D., Davies, J.M., Dolan, L. (2003). Reactive oxygen species produced by NADPH oxidase regulate plant cell growth. Nature. 422: 442-446.

Forlani, S., Masiero, S., Mizzotti, C. (2019). Fruit ripening: the role of hormones, cell wall modifications and their intersection with pathogens. J. Exp. Bot.

Frolich, E.F., Platt, R.G. (1972). Use of the etiolation technique in rooting avocado cuttings. California Avocado Society 1971-72 Yearbook. 55: 97-109.

Fu, Y., Gu, Y., Zheng, Z., Wasteneys, G., Yang, Z. (2005). Arabidopsis interdigitating cell growth requires two antagonistic pathways with opposing action on cell morphogenesis. Cell. 120: 687-700.

Fuglsang, A.T., Visconti, S., Drumm, K., Jahn, T., Stensballe, A., Mattei, B., Jensen, O.N., Aducci, P., Palmgren, M.G. (1999). Binding of 14-3-3 protein to the plasma membrane $\mathrm{H}(+)$-ATPase AHA2 involves the three C-terminal residues Tyr(946)-Thr-Val and requires phosphorylation of $\operatorname{Thr}(947)$. J. Biol. Chem. 274: 36774-36780. 
Fujita, M., Himmelspach, R., Ward, J., Whittington, A., Hasenbein, N., Liu, C., Truong, T.T., Galway, M.E., Mansfield, S.D., Hocart, C.H., Wasteneys, G.O. (2013a). The anisotropy1 D604N mutation in the Arabidopsis cellulose synthase 1 catalytic domain reduces cell wall crystallinity and the velocity of cellulose synthase complexes. Plant Physiol. 162: 74-85.

Fujita, S., Pytela, J., Hotta, T., Kato, T., Hamada, T., Akamatsu, R., Ishida, Y., Kutsuna, N., Hasezawa, S., Nomura, Y., Nakagami, H., Hashimoto, T. (2013b). An atypical tubulin kinase mediates stress-induced microtubule depolymerization in Arabidopsis. Curr. Biol. 23: 1969-1978.

Gille, S., Sharma, V., Baidoo, E.E., Keasling, J.D., Scheller, H.V., Pauly, M. (2013). Arabinosylation of a Yariv-precipitable cell wall polymer impacts plant growth as exemplified by the Arabidopsis glycosyltransferase mutant ray1. Mol. Plant. 6: 1369-1372.

Goh, T., Joi, S., Mimura, T., Fukaki, H. (2012). The establishment of asymmetry in Arabidopsis lateral root founder cells is regulated by LBD16/ASL18 and related LBD/ASL proteins. Development. 139: 883-893.

Gonneau, M., Desprez, T., Martin, M., Doblas, V.G., Bacete, L., Miart, F., Sormani, R., Hematy, K., Renou, J., Landrein, B., Murphy, E., Van De Cotte, B., Vernhettes, S., De Smet, I., Hofte, H. (2018). Receptor kinase THESEUS1 is a rapid alkalinization factor 34 receptor in Arabidopsis. Curr. Biol. 28: 2452-2458. e2454.

Guenin, S., Mareck, A., Rayon, C., Lamour, R., Assoumou Ndong, Y., Domon, J.M., Senechal, F., Fournet, F., Jamet, E., Canut, H., Percoco, G., Mouille, G., Rolland, A., Rusterucci, C., Guerineau, F., Van Wuytswinkel, O., Gillet, F., Driouich, A., Lerouge, P., Gutierrez, L., Pelloux, J. (2011). Identification of pectin methylesterase 3 as a basic pectin methylesterase isoform involved in adventitious rooting in Arabidopsis thaliana. New Phytol. 192: 114-126.

Gutierrez, L., Bussell, J.D., Pacurar, D.I., Schwambach, J., Pacurar, M., Bellini, C. (2009). Phenotypic plasticity of adventitious rooting in Arabidopsis is controlled by complex regulation of AUXIN RESPONSE FACTOR transcripts and microRNA abundance. Plant Cell. 21: 3119-3132.

Hamant, O., Meyerowitz, E.M., Traas, J. (2011). Is cell polarity under mechanical control in plants? Plant Signal. Behav. 6: 137-139.

Hartmann, H.T., Kester, D.E., Davies, F.T.J., Geneve, R.L. (2011). Hartmann and Kester's Plant Propagation. Principles and Practices. Eighth Edition. Pearson Education Limited, Essex, Great Britain.

Haruta, M., Sabat, G., Stecker, K., Minkoff, B.B., Sussman, M.R. (2014). A peptide hormone and its receptor protein kinase regulate plant cell expansion. Science. 343: 408-411.

Heisler, M.G., Hamant, O., Krupinski, P., Uyttewaal, M., Ohno, C., Jonsson, H., Traas, J., Meyerowitz, E.M. (2010). Alignment between PIN1 polarity and microtubule orientation in the shoot apical meristem reveals a tight coupling between morphogenesis and auxin transport. PLoS Biol. 8: e1000516.

Hematy, K., Sado, P.E., Van Tuinen, A., Rochange, S., Desnos, T., Balzergue, S., Pelletier, S., Renou, J.P., Hofte, H. (2007). A receptor-like kinase mediates the response of Arabidopsis cells to the inhibition of cellulose synthesis. Curr. Biol. 17: 922-931.
Huang, W.N., Liu, H.K., Zhang, H.H., Chen, Z., Guo, Y.D., Kang, Y.F. (2013). Ethylene-induced changes in lignification and cell wall-degrading enzymes in the roots of mungbean (Vigna radiata) sprouts. Plant Physiol. Biochem. 73: 412-419.

Huck, N., Moore, J.M., Federer, M., Grossniklaus, U. (2003). The Arabidopsis mutant feronia disrupts the female gametophytic control of pollen tube reception. Development. 130: 2149-2159.

Hutchison, K.W., Singer, P.B., McInnis, S., Diaz-Sala, C., Greenwood, M.S. (1999). Expansins are conserved in conifers and expressed in hypocotyls in response to exogenous auxin. Plant Physiol. 120: 827-832.

Kierzkowski, D., Nakayama, N., Routier-Kierzkowska, A.L., Weber, A., Bayer, E., Schorderet, M., Reinhardt, D., Kuhlemeier, C., Smith, R.S. (2012). Elastic domains regulate growth and organogenesis in the plant shoot apical meristem. Science. 335: 1096-1099.

Knox, J.P., Linstead, P.J., King, J., Cooper, C., Roberts, K. (1990). Pectin esterification is spatially regulated both within cell walls and between developing tissues of root apices. Planta. 181: 512-521.

Konishi, M., Sugiyama, M. (2003). Genetic analysis of adventitious root formation with a novel series of temperaturesensitive mutants of Arabidopsis thaliana. Development. 130: 5637-5647.

Kumpf, R.P., Shi, C.L., Larrieu, A., Sto, I.M., Butenko, M.A., Peret, B., Riiser, E.S., Bennett, M.J., Aalen, R.B. (2013). Floral organ abscission peptide IDA and its HAE/HSL2 receptors control cell separation during lateral root emergence. Proc. Natl. Acad. Sci. U S A. 110: 5235-5240.

Lakehal, A., Bellini, C. (2019). Control of adventitious root formation: insights into synergistic and antagonistic hormonal interactions. Physiol. Plant. 165: 90-100.

Landrein, B., Hamant, O. (2013). How mechanical stress controls microtubule behavior and morphogenesis in plants: history, experiments and revisited theories. Plant J. 7: 324-338.

Laplaze, L., Parizot, B., Baker, A., Ricaud, L., Martiniere, A., Auguy, F., Franche, C., Nussaume, L., Bogusz, D., Haseloff, J. (2005). GAL4-GFP enhancer trap lines for genetic manipulation of lateral root development in Arabidopsis thaliana. J. Exp. Bot. 56: 2433-2442.

Laskowski, M., Grieneisen, V.A., Hofhuis, H., Hove, C.A., Hogeweg, P., Maree, A.F., Scheres, B. (2008). Root system architecture from coupling cell shape to auxin transport. PLOS Biol. 6: e307.

Lerouxel, O., Cavalier, D.M., Liepman, A.H., Keegstra, K. (2006). Biosynthesis of plant cell wall polysaccharides - a complex process. Curr. Opin. Plant Biol. 9: 621-630.

Li, S., Lei, L., Somerville, C.R., Gu, Y. (2012). Cellulose synthase interactive protein 1 (CSI1) links microtubules and cellulose synthase complexes. Proc. Natl. Acad. Sci. U S A. 109: 185-190.

Liao, W.-B., Zhang, M.-L., Huang, G.-B., Yu, J.-H. (2012). Ca2+ and $\mathrm{CaM}$ are Involved in NO- and $\mathrm{H} 2 \mathrm{O} 2$-Induced Adventitious Root Development in Marigold. J. Plant Growth Reg. 31: 253-264.

Lin, D., Cao, L., Zhou, Z., Zhu, L., Ehrhardt, D., Yang, Z., Fu, Y. (2013). Rho GTPase signaling activates microtubule severing 
to promote microtubule ordering in Arabidopsis. Curr. Biol. 23: 290-297.

Lin, D., Nagawa, S., Chen, J., Cao, L., Chen, X., Xu, T., Li, H., Dhonukshe, P., Yamamuro, C., Friml, J., Scheres, B., Fu, Y., Yang, Z. (2012). A ROP GTPase-Dependent Auxin Signaling Pathway Regulates the Subcellular Distribution of PIN2 in Arabidopsis Roots. Curr. Biol. 22: 1319-1325.

Lucas, M., Kenobi, K., von Wangenheim, D., Vobeta, U., Swarup, K., De Smet, I., Van Damme, D., Lawrence, T., Peret, B., Moscardi, E., Barbeau, D., Godin, C., Salt, D., Guyomarc'h, S., Stelzer, E.H., Maizel, A., Laplaze, L., Bennett, M.J. (2013). Lateral root morphogenesis is dependent on the mechanical properties of the overlaying tissues. Proc. Natl. Acad. Sci. U S A. 110: 5229-5234.

Ma, F., Wang, L., Li, J., Samma, M.K., Xie, Y., Wang, R., Wang, J., Zhang, J., Shen, W. (2014). Interaction between HY1 and $\mathrm{H} 2 \mathrm{O} 2$ in auxin-induced lateral root formation in Arabidopsis. Plant Mol. Biol. 85: 49-61.

Malamy, J.E., Benfey, P.N. (1997). Organization and cell differentiation in lateral roots of Arabidopsis thaliana. Development. 124: 33-44.

Manzano, C., Pallero-Baena, M., Casimiro, I., De Rybel, B., OrmanLigeza, B., Van Isterdael, G., Beeckman, T., Draye, X., Casero, P., Del Pozo, J.C. (2014). The Emerging Role of Reactive Oxygen Species Signaling during Lateral Root Development. Plant Physiol. 165: 1105-1119.

Marhavy, P., Montesinos, J.C., Abuzeineh, A., Van Damme, D. Vermeer, J.E., Duclercq, J., Rakusova, H., Novakova, P., Friml, J., Geldner, N., Benkova, E. (2016). Targeted cell elimination reveals an auxin-guided biphasic mode of lateral root initiation. Genes Dev. 30: 471-483.

McFarlane, H.E., Doring, A., Persson, S. (2014). The cell biology of cellulose synthesis. Annu. Rev. Plant Biol. 65: 69-94.

Merelo, P., Agusti, J., Arbona, V., Costa, M.L., Estornell, L.H., Gomez-Cadenas, A., Coimbra, S., Gomez, M.D., Perez-Amador, M.A., Domingo, C., Talon, M., Tadeo, F.R. (2017). Cell Wall Remodeling in Abscission Zone Cells during Ethylene-Promoted Fruit Abscission in Citrus. Front. Plant Sci. 8: 126.

Micheli, F., Sundberg, B., Goldberg, R., Richard, L. (2000). Radial distribution pattern of pectin methylesterases across the cambial region of hybrid aspen at activity and dormancy. Plant Physiol. 124: 191-199.

Monshausen, G.B., Haswell, E.S. (2013). A force of nature: molecular mechanisms of mechanoperception in plants. J. Exp. Bot. 64: 4663-4680.

Murphy, E., Vu, L.D., Van den Broeck, L., Lin, Z., Ramakrishna, P., van de Cotte, B., Gaudinier, A., Goh, T., Slane, D., Beeckman, T., Inze, D., Brady, S.M., Fukaki, H., De Smet, I. (2016). RALFL34 regulates formative cell divisions in Arabidopsis pericycle during lateral root initiation. J. Exp. Bot. 67: 4863-4875.

Oda, Y. (2015). Cortical microtubule rearrangements and cell wall patterning. Front. Plant Sci. 6: 236.

Orman-Ligeza, B., Parizot, B., de Rycke, R., Fernandez, A., Himschoot, E., Van Breusegem, F., Bennett, M.J., Perilleux, C., Beeckman, T., Draye, X. (2016). RBOH-mediated ROS production facilitates lateral root emergence in Arabidopsis. Development. 143: 3328-3339.
Pagnussat, G.C., Lanteri, M.L., Lamattina, L. (2003). Nitric oxide and cyclic GMP are messengers in the indole acetic acidinduced adventitious rooting process. Plant Physiol. 132: 1241-1248.

Pagnussat, G.C., Lanteri, M.L., Lombardo, M.C., Lamattina, L. (2004). Nitric oxide mediates the indole acetic acid induction activation of a mitogen-activated protein kinase cascade involved in adventitious root development. Plant Physiol. 135: 279-286.

Pagnussat, G.C., Simontacchi, M., Puntarulo, S., Lamattina, L. (2002). Nitric oxide is required for root organogenesis. Plant Physiol. 129: 954-956.

Paredez, A.R., Somerville, C.R., Ehrhardt, D.W. (2006). Visualization of Cellulose Synthase Demonstrates Functional Association with Microtubules. Science. 312: 1491-1495.

Park, Y.B., Cosgrove, D.J. (2012). Changes in cell wall biomechanical properties in the xyloglucan-deficient xxt1/xxt2 mutant of Arabidopsis. Plant Physiol. 158: 465-475.

Pastuglia, M., Azimzadeh, J., Goussot, M., Camilleri, C., Belcram, K., Evrard, J.L., Schmit, A.C., Guerche, P., Bouchez, D. (2006). Gamma-tubulin is essential for microtubule organization and development in Arabidopsis. Plant Cell. 18: 1412-1425.

Peaucelle, A., Braybrook, S., Hofte, H. (2012). Cell wall mechanics and growth control in plants: the role of pectins revisited. Front. Plant Sci. 3: 121.

Peaucelle, A., Braybrook, S.A., Le Guillou, L., Bron, E., Kuhlemeier, C., Hofte, H. (2011). Pectin-induced changes in cell wall mechanics underlie organ initiation in Arabidopsis. Curr. Biol. 21: 1720-1726.

Peaucelle, A., Wightman, R., Hofte, H. (2015). The Control of Growth Symmetry Breaking in the Arabidopsis Hypocotyl. Curr. Biol. 25: 1746-1752.

Pelloux, J., Rusterucci, C., Mellerowicz, E.J. (2007). New insights into pectin methylesterase structure and function. Trends Plant Sci. 12: 267-277.

Peret, B., Li, G., Zhao, J., Band, L.R., Voss, U., Postaire, O., Luu, D.T., Da Ines, O., Casimiro, I., Lucas, M., Wells, D.M., Lazzerini, L.,Nacry, P., King, J.R., Jensen, O.E., Schaffner, A.R., Maurel, C., Bennett, M.J. (2012). Auxin regulates aquaporin function to facilitate lateral root emergence. Nat. Cell Biol. 14: 991-998.

Pien, S., Wyrzykowska, J., McQueen-Mason, S., Smart, C., Fleming, A. (2001). Local expression of expansin induces the entire process of leaf development and modifies leaf shape. Proc. Natl. Acad. Sci. U S A. 98: 11812-11817.

Pizarro, A., Diaz-Sala, C. (2019). Cellular dynamics during maturation-related decline of adventitious root formation in forest tree species. Physiol. Plant. 165: 73-80.

Ramakrishna, P., Ruiz Duarte, P., Rance, G.A., Schubert, M., Vordermaier, V., Vu, L.D., Murphy, E., Vilches Barro, A., Swarup, K., Moirangthem, K., Jorgensen, B., van de Cotte, B., Goh, T., Lin, Z., Vobeta, U., Beeckman, T., Bennett, M.J., Gevaert, K., Maizel, A., De Smet, I. (2019). EXPANSIN A1-mediated radial swelling of pericycle cells positions anticlinal cell divisions during lateral root initiation. Proc. Natl. Acad. Sci. U S A. 116: 8597-8602.

Rayle, D.L., Cleland, R.E. (1992). The Acid Growth Theory of auxin-induced cell elongation is alive and well. Plant Physiol. 99: 1271-1274. 
Reinhardt, D., Pesce, E.R., Stieger, P., Mandel, T., Baltensperger, K., Bennett, M., Traas, J., Friml, J., Kuhlemeier, C. (2003). Regulation of phyllotaxis by polar auxin transport. Nature. 426: 255-260.

Reiter, W.D., Chapple, C., Somerville, C.R. (1997). Mutants of Arabidopsis thaliana with altered cell wall polysaccharide composition. Plant J. 12: 335-345.

Richter, G.L., Monshausen, G.B., Krol, A., Gilroy, S. (2009). Mechanical stimuli modulate lateral root organogenesis. Plant Physiol. 151: 1855-1866.

Rigal, A., Yordanov, Y.S., Perrone, I., Karlberg, A., Tisserant, E., Bellini, C., Busov, V.B., Martin, F., Kohler, A., Bhalerao, R., Legue, V. (2012). The AINTEGUMENTA LIKE1 homeotic transcription factor PtAIL1 controls the formation of adventitious root primordia in poplar. Plant Physiol. 160: 1996-2006.

Rounds, C.M., Lubeck, E., Hepler, P.K., Winship, L.J. (2011). Propidium iodide competes with $\mathrm{Ca}(2+)$ to label pectin in pollen tubes and Arabidopsis root hairs. Plant Physiol. 157: 175-187.

Roycewicz, P.S., Malamy, J.E. (2014). Cell wall properties play an important role in the emergence of lateral root primordia from the parent root. J Exp Bot. 65: 2057-2069.

Sahaf, M., Sharon, E. (2016). The rheology of a growing leaf: stress-induced changes in the mechanical properties of leaves. J. Exp. Bot. 67: 5509-5515.

Sampathkumar, A., Yan, A., Krupinski, P., Meyerowitz, E.M. (2014). Physical forces regulate plant development and morphogenesis. Curr. Biol. 24: R475-483.

Sanati Nezhad, A., Naghavi, M., Packirisamy, M., Bhat, R., Geitmann, A. (2013). Quantification of cellular penetrative forces using lab-on-a-chip technology and finite element modeling. Proc. Natl. Acad. Sci. U S A. 110: 8093-8098.

Sassi, M., Ali, O., Boudon, F., Cloarec, G., Abad, U., Cellier, C., Chen, X., Gilles, B., Milani, P., Friml, J., Vernoux, T., Godin, C., Hamant, O., Traas, J. (2014). An Auxin-Mediated Shift toward Growth Isotropy Promotes Organ Formation at the Shoot Meristem in Arabidopsis. Curr. Biol. 24: 2335-2342.

Sassi, M., Traas, J. (2015). When biochemistry meets mechanics: a systems view of growth control in plants. Curr. Opin. Plant Biol. 28: 137-143.

Savatin, D.V., Ferrari, S., Sicilia, F., De Lorenzo, G. (2011). Oligogalacturonide-auxin antagonism does not require posttranscriptional gene silencing or stabilization of auxin response repressors in Arabidopsis. Plant Physiol. 157: 1163-1174.

Schallus, T., Jaeckh, C., Feher, K., Palma, A.S., Liu, Y., Simpson, J.C., Mackeen, M., Stier, G., Gibson, T.J., Feizi, T., Pieler, T., MuhleGoll, C. (2008). Malectin: a novel carbohydrate-binding protein of the endoplasmic reticulum and a candidate player in the early steps of protein N-glycosylation. Mol. Biol. Cell. 19: 3404-3414.

Schoenaers, S., Balcerowicz, D., Breen, G., Hill, K., Zdanio, M., Mouille, G., Holman, T.J., Oh, J., Wilson, M.H., Nikonorova, N., Vu, L.D., De Smet, I., Swarup, R., De Vos, W.H., Pintelon, I., Adriaensen, D., Grierson, C., Bennett, M.J., Vissenberg, K. (2018). The Auxin-Regulated CrRLK1L Kinase ERULUS Controls Cell Wall Composition during Root Hair Tip Growth. Curr. Biol. 28: 722-732.e726.
Schulze-Muth, P., Irmler, S., Schroder, G., Schroder, J. (1996). Novel type of receptor-like protein kinase from a higher plant (Catharanthus roseus). cDNA, gene, intramolecular autophosphorylation, and identification of a threonine important for auto- and substrate phosphorylation. J. Biol. Chem. 271: 26684-26689.

Senechal, F., Graff, L., Surcouf, O., Marcelo, P., Rayon, C., Bouton, S., Mareck, A., Mouille, G., Stintzi, A., Hofte, H., Lerouge, P., Schaller, A., Pelloux, J. (2014a). Arabidopsis PECTIN METHYLESTERASE17 is co-expressed with and processed by SBT3.5, a subtilisin-like serine protease. Ann. Bot. 114: 1161-1175.

Senechal, F., Wattier, C., Rusterucci, C., Pelloux, J. (2014b). Homogalacturonan-modifying enzymes: structure, expression, and roles in plants. J. Exp. Bot. 65: 5125-5160.

Shih, H.W., Miller, N.D., Dai, C., Spalding, E.P., Monshausen, G.B. (2014). The receptor-like kinase FERONIA is required for mechanical signal transduction in Arabidopsis seedlings. Curr. Biol. 24: 1887-1892.

Sinclair, S.A., Larue, C., Bonk, L., Khan, A., Castillo-Michel, H., Stein, R.J., Grolimund, D., Begerow, D., Neumann, U., Haydon, M.J., Kramer, U. (2017). Etiolated Seedling Development Requires Repression of Photomorphogenesis by a Small Cell-Wall-Derived Dark Signal. Curr. Biol. 27: 34033418.e3407.

Smirnova, A.V., Matveyeva, N.P., Yermakov, I.P. (2014). Reactive oxygen species are involved in regulation of pollen wall $c y-$ tomechanics. Plant Biol (Stuttg). 16: 252-257.

Somerville, C. (2006). Cellulose synthesis in higher plants. Annu. Rev. Cell Dev. Biol. 22: 53-78.

Somerville, C., Bauer, S., Brininstool, G., Facette, M., Hamann, T., Milne, J., Osborne, E., Paredez, A., Persson, S., Raab, T., Vorwerk, S., Youngs, H. (2004). Toward a systems approach to understanding plant cell walls. Science. 306: 2206-2211.

Spartz, A.K., Ren, H., Park, M.Y., Grandt, K.N., Lee, S.H., Murphy, A.S., Sussman, M.R., Overvoorde, P.J., Gray, W.M. (2014). SAUR inhibition of PP2C-D phosphatases activates plasma membrane $\mathrm{H}+$-ATPases to promote cell expansion in Arabidopsis. Plant Cell. 26:2129-2142.

Steffens, B., Kovalev, A., Gorb, S.N., Sauter, M. (2012). Emerging Roots Alter Epidermal Cell Fate through Mechanical and Reactive Oxygen Species Signaling. Plant Cell. 24: 3296-3306.

Steffens, B., Rasmussen, A. (2016). The Physiology of Adventitious Roots. Plant Physiol. 170: 603-617.

Swarup, K., Benkova, E., Swarup, R., Casimiro, I., Peret, B., Yang, Y., Parry, G., Nielsen, E., De Smet, I., Vanneste, S., Levesque, M.P., Carrier, D., James, N., Calvo, V., Ljung, K., Kramer, E., Roberts, R., Graham, N., Marillonnet, S., Patel, K., Jones, J.D., Taylor, C.G., Schachtman, D.P., May, S., Sandberg, G., Benfey, P., Friml, J., Kerr, I., Beeckman, T., Laplaze, L., Bennett, M.J. (2008). The auxin influx carrier LAX3 promotes lateral root emergence. Nat. Cell Biol. 10: 946-954.

Verhertbruggen, Y., Marcus, S.E., Haeger, A., Ordaz-Ortiz, J.J., Knox, J.P. (2009). An extended set of monoclonal antibodies to pectic homogalacturonan. Carbohydr Res. 344: 1858-1862.

Vermeer, J.E., von Wangenheim, D., Barberon, M., Lee, Y., Stelzer, E.H., Maizel, A., Geldner, N. (2014). A spatial accommodation 
by neighboring cells is required for organ initiation in Arabidopsis. Science. 343: 178-183.

Verstraeten, I., Schotte, S., Geelen, D. (2014). Hypocotyl adventitious root organogenesis differs from lateral root development. Front. Plant Sci. 5: 495.

Vilasboa, J., Da Costa, C.T., Fett-Neto, A.G. (2018). Rooting of eucalypt cuttings as a problem-solving oriented model in plant biology. Prog. Biophys. Mol. Biol.

Vilches-Barro, A., Maizel, A. (2015). Talking through walls: mechanisms of lateral root emergence in Arabidopsis thaliana. Curr. Opin. Plant. Biol. 23: 31-38.

Vilches Barro, A., Stoeckle, D., Thellmann, M., Ruiz Duarte, P. Bald, L., Louveaux, M., von Born, P., Denninger, P., Goh, T., Fukaki, H., Vermeer, J., Maizel, A. (2019). Cytoskeleton dynamics control early events of lateral root initiation in Arabidopsis. bioRxiv. 559443.

Wagner, T.A., Kohorn, B.D. (2001). Wall-Associated Kinases Are Expressed throughout Plant Development and Are Required for Cell Expansion. Plant Cell. 13: 303-318.

Wasteneys, G.O., Galway, M.E. (2003). Remodelling the cytoskeleton for growth and form: An overview with some new views. Ann. Rev. Plant Biol. 54: 691-722.
Whittington, A.T., Vugrek, O., Wei, K.J., Hasenbein, N.G., Sugimoto, K., Rashbrooke, M.C., Wasteneys, G.O. (2001). MOR1 is essential for organizing cortical microtubules in plants. Nature. 411: 610-613.

Wormit, A., Usadel, B. (2018). The Multifaceted Role of Pectin Methylesterase Inhibitors (PMEIs). Int J Mol Sci. 19.

Xiao, C., Somerville, C., Anderson, C.T. (2014). POLYGALACTURONASE INVOLVED IN EXPANSION1 functions in cell elongation and flower development in Arabidopsis. Plant Cell. 26: 1018-1035.

Zhang, W., Cai, C., Staiger, C.J. (2019). Myosins XI Are Involved in Exocytosis of Cellulose Synthase Complexes. Plant Physiol. 179: 1537-1555.

Zhu, Q., Shao, Y., Ge, S., Zhang, M., Zhang, T., Hu, X., Liu, Y., Walker, J., Zhang, S., Xu, J. (2019). A MAPK cascade downstream of IDA-HAE/HSL2 ligand-receptor pair in lateral root emergence. Nat. Plants. 5: 414-423. 
